\title{
Screening of Soybean Genotypes to Soybean Yellow Mosaic Virus Disease
}

\author{
Y. B. Naveesh ${ }^{1 *}$, H. A. Prameela, S. Basavaraj and K. T. Rangaswamy \\ Department of Plant pathology, UAS, GKVK, Bengaluru, Karnataka 560065, India \\ *Corresponding author
}

\section{A B S T R A C T}

\begin{tabular}{l} 
Ke y w o r d s \\
Genotypes, \\
Screening, \\
SYMV, \\
Whiteflies \\
\hline Article Info \\
\hline $\begin{array}{l}\text { Accepted: } \\
\text { 15 February } 2020 \\
\text { Available Online: } \\
\text { 10 March } 2020\end{array}$ \\
\hline
\end{tabular}

\begin{abstract}
Forty-three genotypes of soybean were screened for soybean yellow mosaic virus disease (SYMV) under glasshouse condition using viruliferous whiteflies (Bemesia tabaci) through artificial virus inoculation method. Among 43 genotypes none of the genotypes were found highly resistance to the disease. Eleven genotypes viz., KDS-378, RKS-118, Bragg, DS-2706, DSb-25, Dsb-23, MAUS-2, DSb-21, DS-2708, DS-2006 and DS-2707 were found moderately resistance(MR) to soybean yellow mosaic virus (SYMV), 6 genotypes showed moderately susceptible to SYMV, 21 genotype showed susceptible reaction to SYMV and 5 genotypes showed highly susceptible to SYMV viz., JS-335, JS-20, B20-41, RVS-208, CSB-904.
\end{abstract}

\section{Introduction}

Soybean [Glycine max (L.) Merrill] is a species of legume native to East Asia. The plant is classified as an oilseed rather than a pulse by UN Food and Agricultural Organization (FAO). It is known as the 'Golden bean' or 'Super legume' of the twentieth century. Soybean oil is a good source of polyunsaturated fatty acids, such as linoleic acid and alphalinolenic acid which are good for human health. It is one of the best vegetarian sources of total proteins containing all essential amino acids required in the human diet. Soybean oil and protein content account for 60 per cent of dry soybeans by weight Protein at 40 per cent and oil at 20 per cent. The beans contain significant amounts of phytic acid, alphalinolenic acid, and isoflavones (Anon., 2012).

Soybean is the major oil seed crop of the world including India. It is affected by several diseases viz., Rust (Phakopsora pachyrhizi), Alternaria leaf spot (Alternaria spp.), Downey mildew (Peronospora manshurica), Bacterial leaf spot (Xanthomonas campestris pv.glycines), Anthracnose (Colletotrichum spp), Charcoal rot (Macrophomina phaseolina), Purple seed stain (Cercospora kikuchii), Soybean cyst nematode (Heterodera glycines) and viral diseases. 
Yellow mosaic virus (YMV), soybean mosaic virus (SMV) and groundnut bud necrosis virus (GBNV), bean pea mottle virus, soybean crinkle leaf geminivirus, cowpea mild mottle carla virus (CMMV) are the major viral Diseases of soybean in India (Lal et al., 2005). Among the viral diseases, yellow mosaic virus disease has been considered as an economically important disease, which is a limiting factor on crop growth and yield.

Soybean yellow mosaic virus (SYMV) is a serious and widespread disease of soybean in the Northern India, part of South India, Srilanka, Bangladesh, Pakistan and Thailand (Bhattacharyya et al., 1999). Yellow mosaic disease on soybean was first reported in North India in the early 1970's. Then it was being spread at alarming proportions. Its expansion towards central India or the hub of the country for soybean cultivation might be fatal to the soybean industry. Nearly all the varieties grown in the central India are susceptible to YMV. The magnitude of yield loss due to YMV in soybean has been reported to be as high as 80 per cent (Nene, 1972a).

\section{Materials and Methods}

\section{Collection of soybean yellow mosaic virus disease samples}

Samples of soybean yellow mosaic virus disease were collected from the fields, in polythene covers and were maintained on healthy plants by inoculating through whitefly vector, B. tabaci

Maintenance of whitefly culture and handling of whiteflies

The pure culture of indigenous whiteflies $B$. tabaci used for viral transmission were maintained on cotton, Gossypium hirsutum cv. Varalakshmi and brinjal plants kept in insect proof wooden cages $(45 \mathrm{~cm} \mathrm{x} 45 \mathrm{~cm} \mathrm{x}$ $30 \mathrm{~cm}$ ) and muslin cloth was pasted on three sides and the top with fevicol. The front side was covered with glass, which could be moved easily in the grooves made in the wooden framework. The colony was maintained by introducing healthy cotton plants grown in polythene bags $(4 \mathrm{~cm} \times 6 \mathrm{~cm})$ in to the cages. The cages were maintained at the temperature of $28 \pm 2{ }^{\circ} \mathrm{C}$ in an insect proof polyhouse. The whiteflies were allowed to colonize on the ventral surface of the Young leaflets of cotton and brinjal. After one cycle, freshly hatched whiteflies were free from any viruses and used for further transmission studies.

\section{Collection of whiteflies}

An aspirator made of a glass tube $(30 \mathrm{~cm} \mathrm{x}$ $0.5 \mathrm{~cm} \times 40 \mathrm{~cm}$ ) and a rubber tube of $40 \mathrm{~cm}$ length was used for the collection of whiteflies (Plate 5). The leaves colonized with healthy whiteflies were turned slightly upwards and the flies were sucked in to the glass tube. Later, they were gently blown into the plastic tubes. The virus free whiteflies thus collected were used in this investigation.

\section{Raising healthy soybean seedlings}

Seeds of soybean were sown in $4 \mathrm{x}$ 6inch polythene bag filled with pot mixture containing soil and compost in $2: 1$ proportion. The polythene bags were kept in insect proof cages. Then seedlings which are 8-10 days old (i.e., after germination) were used as test plants for screening study experiments.

\section{Maintenance of yellow mosaic virus culture on soybean}

Soybean plants showing conspicuous symptoms of yellow mosaic were collected from naturally infected plants from the fields, 
Main Research Station, Hebbal, Bengaluru. Whiteflies B. tabaci were released for the acquisition of virus for $24 \mathrm{hr}$. The viruliferous whiteflies were later transferred to seven days old healthy soybean seedlings in a glasshouse. The inoculation access period of $24 \mathrm{hr}$ was given for transmission of virus. The inoculated plants were kept in insect proof cages for the expression of yellow mosaic virus disease symptoms and they were used as stock culture. The same culture was maintained in a glasshouse by inoculating periodically to the healthy plants of soybean with the viruliferous whiteflies (Bemisia tabaci) for various experiments. Soybean genotypes were screened for resistance against SYMV under glass house condition. The seedlings were raised in insect proof cages and were inoculated at the age of 8 days using viruliferous indigenous $B$. tabaci (AAP and IAP of 24hrs.) at the rate of $10-15$ whiteflies per plant. The plants were transferred to insect proof glasshouse after inoculation and observed for symptom expression. Per cent transmission of disease in each genotype/line was calculated and rating was given based on disease scale.

\section{Per cent disease incidence $=\underline{\text { Number of infected plants }} \times 100$ \\ Total number of plants examine}

\section{Results and Discussion}

Fourty three genotypes /cultivars of soybean were screened against soybean yellow mosaic virus (SYMV) under glasshouse condition using viruliferous vector $B$. tabaci. The results are presented in the (Table: 2). Among forty-three soybean genotypes screened, only eleven genotypes/cultivars viz., KDS-378, RKS-118, Bragg, DS-2706, Dsb-25, DS2708, Dsb-23, MAUS-2, Dsb-21, DS-2707 and DS-2006 were found to be moderately resistant to SYMV (Plate.14). These genotypes showed yellow mottling and discolouration of leaves. Six genotypes/cultivars viz., MACS-1340, MACS-1410, MACS-1407, Monnet, KHSB-2 and Hardee were found to be moderately susceptible to SYMV. These genotypes showed pronounced yellow mottling and discolouration of leaves.

Table.1 Disease scoring scale to soybean yellow mosaic virus disease (SYMV) (Lal et al., 2005)

\begin{tabular}{|l|l|l|}
\hline Scale & Description & Disease reaction \\
\hline $\mathbf{0}$ & $\begin{array}{l}\text { No symptoms on plants } \\
\text { 1-5 per cent plants exhibiting mottling of } \\
\text { leaves symptoms }\end{array}$ & Highly resistant (HR) \\
\hline $\mathbf{1}$ & $\begin{array}{l}\text { 5-15 per cent plants exhibiting mottling } \\
\text { and yellow discolouration symptoms }\end{array}$ & $\begin{array}{l}\text { Moderately resistant } \\
\text { (MR) }\end{array}$ \\
\hline $\mathbf{3}$ & $\begin{array}{l}\text { 15-25 per cent plants exhibiting mottling } \\
\text { and yellow discolouration symptoms }\end{array}$ & $\begin{array}{l}\text { Moderately } \\
\text { susceptible(MS) }\end{array}$ \\
\hline $\mathbf{5}$ & $\begin{array}{l}\text { 25-50 per cent plants exhibiting mottling } \\
\text { and yellow discolouration symptoms } \\
\text { >50 per cent plants exhibiting mottling } \\
\text { and yellow discolouration reduced } \\
\text { flowers and pods }\end{array}$ & Susceptible (S) \\
\hline $\mathbf{7}$ & & Highly susceptible (HS) \\
\hline
\end{tabular}


Table.2 Screening of soybean genotypes/cultivars against soybean yellow mosaic virus (SYMV) under glass house condition

\begin{tabular}{|c|c|c|c|c|c|c|}
\hline \multirow{2}{*}{$\begin{array}{l}\text { Sl. } \\
\text { No }\end{array}$} & \multirow[t]{2}{*}{ Genotypes } & \multicolumn{2}{|c|}{ No. of plants } & \multirow{2}{*}{$\begin{array}{l}\text { Per cent disease } \\
\text { incidence (PDI) }\end{array}$} & \multirow[t]{2}{*}{ Reaction } & \multirow[t]{2}{*}{ Rating } \\
\hline & & Inoculated & Infected & & & \\
\hline 1 & KDS-378 & 15 & 2 & 13.33 & MR & 3 \\
\hline 2 & MACS-1340 & 15 & 3 & 20 & MS & 5 \\
\hline 3 & MACS-1410 & 15 & 3 & 20 & MS & 5 \\
\hline 4 & RKS-118 & 15 & 2 & 13.33 & MR & 3 \\
\hline 5 & MAUS-612 & 15 & 4 & 26.66 & $\mathrm{~S}$ & 7 \\
\hline 6 & JS-335 & 15 & 12 & 80 & HS & 9 \\
\hline 7 & B-20-41 & 15 & 10 & 66.66 & HS & 9 \\
\hline 8 & NRC-92 & 15 & 4 & 26.66 & $\mathrm{~S}$ & 7 \\
\hline 9 & MACS-1370 & 15 & 5 & 33.33 & $\mathrm{~S}$ & 7 \\
\hline 10 & KB-79 & 15 & 7 & 46.66 & $\mathrm{~S}$ & 7 \\
\hline 11 & MACS-1416 & 15 & 6 & 40 & $\mathrm{~S}$ & 7 \\
\hline 12 & KDS-693 & 15 & 4 & 26.66 & $\mathrm{~S}$ & 7 \\
\hline 13 & MACS-1415 & 15 & 6 & 40 & $\mathrm{~S}$ & 7 \\
\hline 14 & MACS-1407 & 15 & 3 & 20 & MS & 5 \\
\hline 15 & MACS-1407 & 15 & 6 & 40 & $\mathrm{~S}$ & 7 \\
\hline 16 & RKS-1131 & 15 & 4 & 26.66 & $\mathrm{~S}$ & 7 \\
\hline 17 & RKS-1131 & 15 & 4 & 26.66 & $\mathrm{~S}$ & 7 \\
\hline 18 & MAUS-614 & 15 & 5 & 33.33 & $\mathrm{~S}$ & 7 \\
\hline 19 & CSB-904 & 15 & 8 & 53.33 & HS & 9 \\
\hline 20 & MAUS-613 & 15 & 4 & 26.66 & $\mathrm{~S}$ & 7 \\
\hline 21 & BRAGG & 15 & 2 & 13.33 & MR & 3 \\
\hline 22 & DS-2706 & 15 & 2 & 13.33 & $\mathrm{MR}$ & 3 \\
\hline 23 & KDS-22 & 15 & 6 & 40 & $\mathrm{~S}$ & 7 \\
\hline 24 & Dsb-25 & 15 & 2 & 13.33 & MR & 3 \\
\hline 25 & JS-98 & 15 & 7 & 46.66 & $\mathrm{~S}$ & 7 \\
\hline 26 & DS-2706 & 15 & 2 & 13.33 & MR & 3 \\
\hline
\end{tabular}


Int.J.Curr.Microbiol.App.Sci (2020) 9(3): 2070-2076

\begin{tabular}{|c|c|c|c|c|c|c|}
\hline 27 & KARUNAE & 15 & 7 & 46.66 & S & 7 \\
\hline 28 & MACS-1394 & 15 & 6 & 40 & $\mathrm{~S}$ & 7 \\
\hline 29 & RVS-208 & 15 & 8 & 53.33 & HS & 9 \\
\hline 30 & Dsb-23 & 15 & 2 & 13.33 & MR & 3 \\
\hline 31 & KDS-705 & 15 & 4 & 26.66 & S & 7 \\
\hline 32 & KDS-708 & 15 & 4 & 26.66 & $\mathrm{~S}$ & 7 \\
\hline 33 & Dsb-21 & 15 & 2 & 13.33 & MR & 3 \\
\hline 34 & MACS-1409 & 15 & 6 & 40 & $\mathrm{~S}$ & 7 \\
\hline 35 & DS-2708 & 15 & 2 & 13.33 & MR & 3 \\
\hline 36 & MAUS-2 & 15 & 2 & 13.33 & MR & 3 \\
\hline 37 & JS-20 & 15 & 12 & 80 & HS & 9 \\
\hline 38 & HARDEE & 15 & 3 & 20 & MS & 5 \\
\hline 39 & KHSB-2 & 15 & 3 & 20 & MS & 5 \\
\hline 40 & MONEET & 15 & 3 & 20 & MS & 5 \\
\hline 41 & MAUS-164 & 15 & 4 & 26.66 & $\mathrm{~S}$ & 7 \\
\hline 42 & DS-2006 & 15 & 2 & 13.33 & MR & 3 \\
\hline 43 & DS-2707 & 15 & 2 & 13.33 & MR & 3 \\
\hline
\end{tabular}


Table.3 Grouping of genotypes/cultivars into different categories for soybean yellow mosaic virus resistance

\begin{tabular}{|l|l|l|c|l|}
\hline Scale & \multicolumn{1}{|c|}{ Description } & \multicolumn{1}{|c|}{$\begin{array}{c}\text { Disease } \\
\text { score } \\
\text { Highly } \\
\text { resistance } \\
\text { (HR) }\end{array}$} & $\begin{array}{c}\text { No. of } \\
\text { genotypes }\end{array}$ & \multicolumn{1}{|c|}{ Go } \\
\hline $\mathbf{0}$ & No symptoms on plants & & \\
\hline $\mathbf{1}$ & $\begin{array}{l}\text { 1-5\% plants exhibiting } \\
\text { mottling of leaves } \\
\text { symptoms }\end{array}$ & $\begin{array}{l}\text { Resistance } \\
\text { (R) }\end{array}$ & $\mathbf{0 0}$ & \\
\hline $\mathbf{3}$ & $\begin{array}{l}5-15 \% \text { plants exhibiting } \\
\text { mottling and yellow } \\
\text { discolouration symptoms }\end{array}$ & $\begin{array}{l}\text { Moderately } \\
\text { resistance } \\
\text { (MR) }\end{array}$ & $\mathbf{1 1}$ & $\begin{array}{l}\text { KDS-378, RKS-118,Bragg, DS- } \\
\text { 2706, DSb-25, DS-2708, Dsb- } \\
\text { 23,MAUS-2, DSb-21,DS-2707 } \\
\text { and DS-2006 }\end{array}$ \\
\hline $\mathbf{5}$ & $\begin{array}{l}\text { 15-25\% plants exhibiting } \\
\text { mottling and yellow } \\
\text { discolouration symptoms }\end{array}$ & $\begin{array}{l}\text { Moderately } \\
\text { susceptible } \\
\text { (MS) }\end{array}$ & $\mathbf{6}$ & $\begin{array}{l}\text { MACS-1340,MACS-1410, } \\
\text { MACS-1408,Monnet,KHSB- } \\
\text { 2,Hardee }\end{array}$ \\
\hline $\mathbf{7}$ & $\begin{array}{l}\text { 25-50\% plants exhibiting } \\
\text { mottling and yellow } \\
\text { discolouration symptoms }\end{array}$ & $\begin{array}{l}\text { Susceptible } \\
\text { (S) }\end{array}$ & $\mathbf{2 1}$ & $\begin{array}{l}\text { KDS-378, RKS-118,Bragg, DS- } \\
\text { 2706, DSb-25, DS-2708, Dsb- } \\
\text { 23,MAUS-2, DSb-21,DS-2707 } \\
\text { and DS-2006 }\end{array}$ \\
\hline $\mathbf{9}$ & $>\begin{array}{l}\text { > 50\%plants exhibiting } \\
\text { mottling and yellow } \\
\text { discolouration reduced } \\
\text { flowers and pods }\end{array}$ & $\begin{array}{l}\text { Highly } \\
\text { Susceptible } \\
\text { (HS) }\end{array}$ & $\mathbf{5}$ & $\begin{array}{l}\text { JS-335, JS-20, B20-41, RVS-208, } \\
\text { CSB-904 }\end{array}$ \\
\hline
\end{tabular}

Twenty-one genotypes /cultivars MAUS-612, NRC-92, KB-79, MACS-1370, MACS-1415, KDS-693, MACS-1416, JS-98, NRC-94, Karunae, NRC-93, MAUS-612, KDS-22, MAUS-614, KDS-693, RKS-1131, MACS1394, KDS-705, KDS-708, MACS-1407, MAUS-164 and MACS-1407 were found susceptible to SYMV. Pronounced yellow mottling and discolouration of leaves, reduction in leaf size and stunting of plants was observed in these cultivars. Five cultivars/genotypes JS-335, JS-20, B20-41, RVS-208 and CSB-904 were found highly susceptible to SYMV. Severe yellow discolouration of leaves, stunting of plants, reduction in pod size, and no grains was noticed in these cultivars.

Evaluation of germplasm entries for disease resistance is a crucial step in controlling plant diseases through host plant resistance. Genes conferring resistance can be to a certain extent identified through routine screening procedures such as germplasm evaluation. In the case of SYMV in soybean, of 43 genotypes screened, 11 entries have been identified exhibiting promising moderate resistance reaction to SYMV resistance. Identification of resistant lines is essential in the ambit of integrated disease management which is an upcoming concept in the field of agriculture. Earlier studies indicated that identification of resistant sources to YMV is a reliable option for controlling this viral disease. Similar type of genotype evaluations were previously documented by several workers (Kumar et al., (2008), Talukdar et al., (2013), Baruah et al., (2014) However, critical investigations are necessary to 
ascertain the resistance level in these germplasm lines and to further confirm them to finally include in breeding programmes.

In conclusion, forty-three genotypes/cultivars of soybean were screened for SYMV under glasshouse condition revealed none of the genotypes were found highly resistance to the disease. Eleven genotypes/cultivars viz., KDS-378, RKS-118, Bragg, DS-2706, DSb25, Dsb-23, MAUS-2, DSb-21, DS-2708, DS2006 and DS-2707 were found moderately resistance to soybean yellow mosaic virus (SYMV).

\section{References}

Anonymous, 2012, Vegetable and Pulse Research: dry beans. Economic research service, U.S. Department of Agriculture.

Bhattacharyya, P. K., Ram, H. H. and KOLE, P. C., 1999, Inheritance of resistance to yellow mosaic virus in interspecific crosses of soybean. Euphytica. 108: 157-159.

Baruah, S., Sharma, M. K., Baishya, D., Sharma, A. A., Borah, R. and Bhuyan, 2014, Genetic variation for seed yield and yellow mosaic virus resistance in soybean [Glycine max (L.) Merrill.]. Int. J. Sci. Res., 4(9):1-5

Kumar, B., Talukdar, A., Verma, K., Girmilla, V., Bala, I., Lal, S. K., Singh, K. P. and Sapra, R. L., 2008, Screening of soybean [Glycine max (L.) Merr.] genotypes for yellow mosaic virus (YMV) disease resistance and their molecular characterization using RGA and SSRs markers. Aust. J. Crop Sci.8(1): 27-34.

Lal, S. K., Rana, V. K. S., Sapra, R. L. and Singh, K. P., 2005, Screening and utilization of soybean germplasm for breeding resistances against mungbean yellow mosaic virus. Soybean Genet News Lett.32: 8083.

Nene, Y. L., 1972a, A study of viral disease of pulse crops in Uttar Pradesh. Res Bull. No. 4., G. B. Pant. Univ. Agri. Tech., Pantnagar, 144 pp

Talukdar, A. G. D., Harish, M., Shivakumar, B., Kumar, K., Verma, S. K., LAL, R. L., Sapra. and Singh, K. P., 2013, Genetics of yellow mosaic virus resistance in cultivated soybean. Legume Res., 36(3): 263-267.

\section{How to cite this article:}

Naveesh, Y. B., H. A. Prameela, S. Basavaraj and Rangaswamy, K. T. 2020. Screening of Soybean Genotypes to Soybean Yellow Mosaic Virus Disease. Int.J.Curr.Microbiol.App.Sci. 9(03): 2070-2076. doi: https://doi.org/10.20546/ijcmas.2020.903.237 